\title{
Current banana distribution in the Peruvian Amazon basin, with attention to the notion of "Aquinquin" in Shipibo society
}

\author{
Mariko Ohashi $^{1, *}$, Toshio Meguro ${ }^{2}$, Motomu Tanaka $^{1}$ and Makoto Inoue ${ }^{1}$ \\ ${ }^{1}$ Graduate School of Agricultural and Life Sciences, the University of Tokyo, 1-1-1 Yayoi, Bunkyo, Tokyo, 113-8657, Japan \\ ${ }^{2}$ Research Fellow of the Japan Society for the Promotion of Science / Graduate School of Frontier Sciences, the University of Tokyo, 5-1-5 \\ Kashiwanoha, Kashiwa, Chiba, 277-8563, Japan \\ *Corresponding author: maarioha@hotmail.com
}

\begin{abstract}
The purpose of this article is to clarify the Shipibo's distribution of bananas, and to consider the current situation regarding the importance of "aquinquin (sharing)" in their society. The Shipibo people practice food distribution as a custom. While bananas are the major staple food that is eaten most frequently, most households do not supply their own needs. They acquire and exchange bananas in various ways: they get the fruit through requests, as gifts, in requital/exchange, and through purchase in the settlement, as well as through requests to harvest made by the "have-nots" or the gift of harvesting permission by the "haves," both of which are made through face-to-face communication, as well as distribution without tacit permission or formal notification by field owners. While the Shipibo people consider "sharing" to be important and expect male villagers to produce bananas by themselves, banana distribution has been practiced in a circle that includes "chiquish (lazy)" people who do not have their own banana fields. However, "lazy" people were recently excluded from this circle because of their lack of "shinna (care for others)." The Shipibo people have continued banana distribution with a core notion of "aquinquin," but it is not an essentialistic and stable custom, rather is the dynamic process of rearrangement for day-to-day as villagers sound out each other's acceptable situations in their daily life.
\end{abstract}

Key words: banana, food distribution, Peruvian Amazon, sharing, Shipibo

\section{INTRODUCTION}

\section{Shipibo and food distribution}

More than $60 \%$ of the land in the Republic of Peru is covered by mature Amazon rain forest. While this area attracts global attention because of its rich biodiversity, deforestation has proceeded with the advance of commercial logging (O'Neill et al. 2001). In this area people depend on natural resources, and as the global movements enter into the area their lives receive more direct influence.

The Shipibo people, who are the object of this study, are Panoan speaking groups. They live within a range of $600 \mathrm{~km}$ alongside the Ucayali River that passes through

1 According to Ekin et al. (1980, 1986), previously the Shipibo, Setebo, and Conibo (or Konibo), which were three major groups equivalent to clans, lived separately. The Setebo were located north of the Shipibo, but were assimilated into the Shipibo through conquest and intermarriage around the 18th century. Pucallpa Town is somewhat of a dividing line between the Shipibo to the north and the Conibo to the south, but the cultural difference is minimal, and their languages were very similar. As extensive intermarriage has largely eliminated the cultural difference between the two groups, these three groups are known overall as "Shipibo-Conibo" or simply "Shipibo." People in the research village identify themselves as "Shipibo."
Amazonian Peru from south to north (Lathrap 1970, Bergman 1980). The Shipibo were one of the more populous ethnic groups in the area with the estimated population of between 40 and 45 thousand in 2003 (Hern 2003). For subsistence the Shipibo people practice swidden cultivation, hunting, fishing and gathering. From these activities, they acquire and consume animal meat, fish, bananas, plantains (Musa spp., hereinafter bananas), and sweet cassava (Manihot esculenta). In daily life, they are said to distribute meat and fish with matrikin in general (Behrens 1992). Inviting acquaintances and other Shipibo to a meal is so usual that when they are eating something and see someone nearby, they call "Come here to eat together (fuman pine)." The changes in their societies in the process of being incorporated into the market economy in recent years have been studied, focusing on the change in 'distribution' to be regarded as traditional social custom (Behrens 1989, Putsche 2000). Behrens (1986) conducted research along the lower Ucayali River in the 1980 s, and found that because

2 Several researchers reported that Shipibo society was characterized by matrilocal residence and sororal polygyny (Behrens 1984, Hern 1977, Murdock 1967). 
villagers were cultivating cash crops to get money, they had less time for hunting and gathering, and more often had to purchase livestock meat in their villages. The prior literature described a situation in which the distribution of meat and fish decreased under outside influences such as a decrease in available food resources and expansion of the monetary economy (Behrens 1992). These studies indicate that Shipibo societies are moving away from the practice of food distribution, which is at their cultural and social core.

On food distribution, hunter-gatherers have been the major target of studies. Their manner of acquisition and distribution of animal meat and fruits were researched in detail (Imamura 1993, Kitanishi 1997). Concerning Shipibo, Bergman (1980) and Behrens (1986) said that in terms of calories, bananas were the most important food. Behrens (1992) observed that when people have many ripe bananas, they give some to other family members. When those who received bananas have many on a subsequent occasion, they reciprocate. Behrens (1992) thus reasoned that banana exchange is means of reducing both spoilage and the risk of temporary food shortages in Shipibo society. However, the way the Shipibo people share bananas was not studied in detail, even though bananas are their staple food. According to the villagers, such behaviours as food distribution and invitation for acquaintance are called aquinquin in the Shipibo language. The basic meaning of aquinquin is "sharing" but the word also implies "helping each other." While food distribution in Shipibo society has been studied in various preceding studies as their typical culture (Behrens 1986, 1992), people's cognitive side, such as their understanding to what extent they must practice "sharing" or the feeling that they have towards "sharing" whether it is positive or negative (Kakeya 1983, Matsumura 2007, Sasaoka 2008), has not been examined so far. Matsumura (2007) discussed from the research in an agrarian society in Ethiopia that food sharing is not automatically and fixedly practiced according to a norm or moral but rather it is conducted with changes as a result of every "negotiation" in their daily life. He also stated that by focusing on the scene of "negotiation," the process of rearrangement of the custom can be grasped (Matsumura 2007).

\section{Research objective and methods}

The purpose of this article is to clarify the Shipibo's production, consumption and distribution of bananas, which are their staple food but their distribution have not been studied in detail, and to consider the current situation regarding the importance of "sharing" in Shipibo society, with attention to the process of interaction among villagers at a time when influence from the outside world is increasing.

This article consists of four parts. The first part presents general information on Shipibo subsistence and the history of a village which is an object of this study. The second explains Shipibo's indigenous land categorization and the history of reclaiming land for swidden cultivation. The purpose of this section is to clarify the local perception about banana production in general. The third investigates the way bananas are used in the village through direct observation (weighting and counting of food stuffs) and the "sharing" actuation of banana before and after harvest from other household. In these analyses, we pay attentions to the kin relations, which were noted to be an important factor in the aforementioned studies (Behrens 1992). The last part discusses the current people's perception of "sharing" and the possibility of its rearrangement in Shipibo society today, based on the participatory observation of the scene of interaction among villagers, with consideration for situations in which banana distribution is avoided. Examining the reason why some villagers stopped "sharing" bananas with others found that people cited local concepts related to food distribution and the other meaning of aquiquin, "helping each other."

The first author stayed in a villager's house in Dos de Mayo Village (D Village) and collected information using the Shipibo language and Spanish. Field studies were conducted for a total of 131 days between November 2008 and January 2009, from April to July and in November 2009, and from February to March 2011. Research methods included semi-structured and openended interviews, participatory observation, noting the number of times food were part of meals, and the weight of bananas. Below we provide detailed explanations of each research topic and how we performed the research.

\section{DISCRIPTION OF THE RESEARCH SITE}

\section{Research site}

D Village is located near an oxbow lake created by the meandering of a branch of the Ucayali River (Fig.1). The

3 While Matsumura (2007) focused on the side of those who give/ distribute food alone, this study addresses the both side of those give and those receive. 


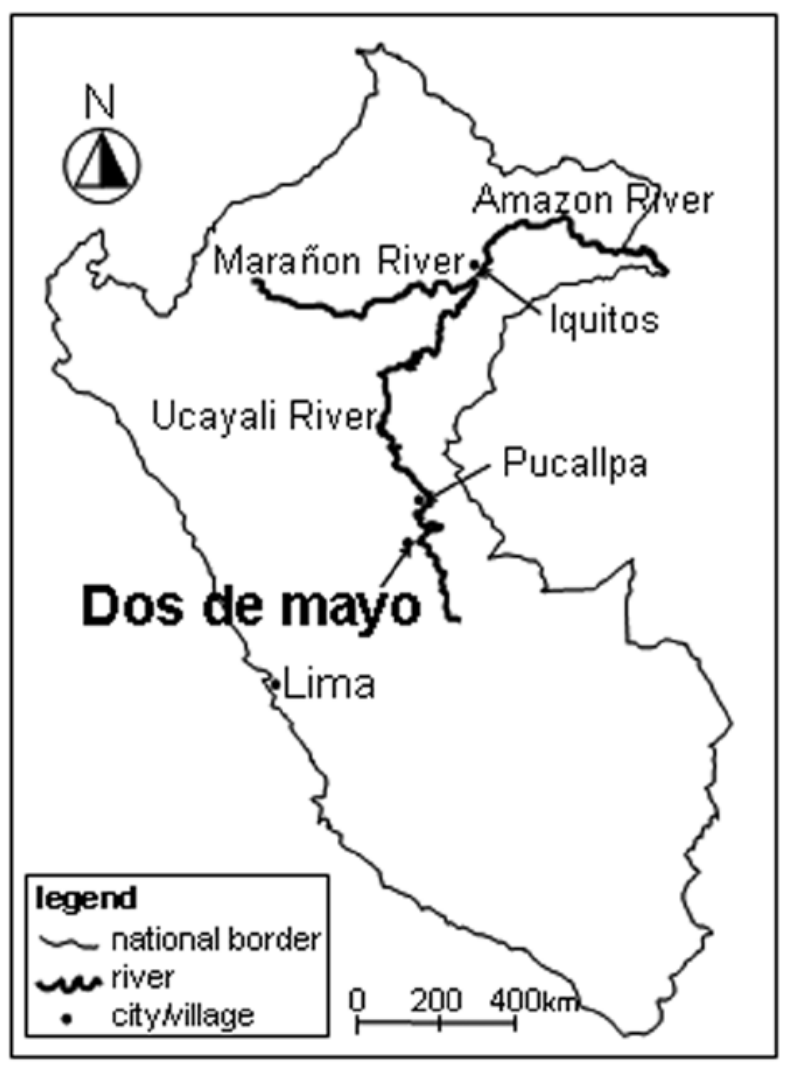

Fig.1. Map of the research site.

average temperature of the research site ranges between 20 and 31 degrees Celsius, and the average rainfall is $966.3 \mathrm{~mm}$. Usually, from September to April is the rainy season and May to August is the dry season. Villagers cultivate bananas and sweet cassava as their staple foods, and rice and maize as cash crops. They also practice fishing and hunting for domestic consumption, and some do seasonal work on papaya plantations or in urban areas. The village has a primary school, a well built by the government, and a village-run kiosk. The kiosk sells daily necessaries such as salt, soap, washbowls, sweets, and snack foods. The nearest market is in Pucallpa City. It takes a whole day from D Village to the city by ferry boat and canoe. Some villagers go to Pucallpa City once a month to sell cash crops and timber at the market, and to visit their families and friends living nearby. In November 2009 the population of D Village was 117 including four Asháninka. In this area, Protestant missionaries were

4 These data refer to the city near the research site. http://eltiempo. es.msn.com/daily_averages.aspx?wealocations=wc:PEXX0019\&q=Puca 1 pa\%2c+PER+forecast:averagesd\&weai=5 (last viewed on November 16, 2010).

5 This article excludes the Asháninka people because they live in a remote area and do not participate in the daily distribution of the other Shipibo villagers. first established in the 1930s (Ekin et al. 1986). In D Village, the major religions are Protestant, and most people subscribe to Evangelicalism, while some are Seventh-day Adventists. The village has had administrative officials since authorization as a jurisdiction in 1984, but villagers say before Christianization Shipibo society had neither hereditary chiefs nor social classes; they had only persons who was shaman (curaca).

Following is a brief history of D Village. In 1977, a shaman came from the upper course of the Ucayali River and approached the current settlement looking for land suitable for cultivation and started swidden cultivation there. After that, two men of different lineages immigrated. In this way, the village came to have three lineages. In 1984 the inhabited land and its surrounding land was registered by the government as an indigenous community, and the village's right of ownership for land around it was officially acknowledged. The villagers said that when commercial logging by a timber company was allowed, animals for food decreased in number. Also, fish became smaller in size after commercial fishing was initiated with big boats by outside companies. Game meat and fish used to be the foods of daily distribution, but nowadays keeping enough for one's own household is difficult, leading to fewer opportunities for "sharing" with others.

\section{Definition of household and mobility of villagers}

In 2009, the usual unit for swidden cultivation and for acquiring and consuming food is those living together in a house, and each household had its own kitchen at home. Before frequent contact with Christian missionaries, the Shipibo lived without forming villages (Hern 2003). Two to three households, which were usually composed of extended families like parents and their children's family (DeBoer and Lathrap 1979), lived together in a place and changed their location while carrying on swidden cultivation. In a settlement, a kitchen is used by multiple residential groups, and the basic unit for the production and consumption of food is the hearth group (Behrens 1992). Currently in D Village, while the nuclear family

6 Myers (1990) stated Shipibo villages of the current size appeared as the result principally of missionary activity in the 19th and early 20th centuries.

7 Some reasons they migrate from place to place are getting away from neighbors with whom they are on unfriendly terms (Bergman 1980), searching for places rich in food resources like fish and animals, and forgetting the sorrow of losing relatives, but it is said that the most frequent is losing their houses because of floods (Bergman 1980). 


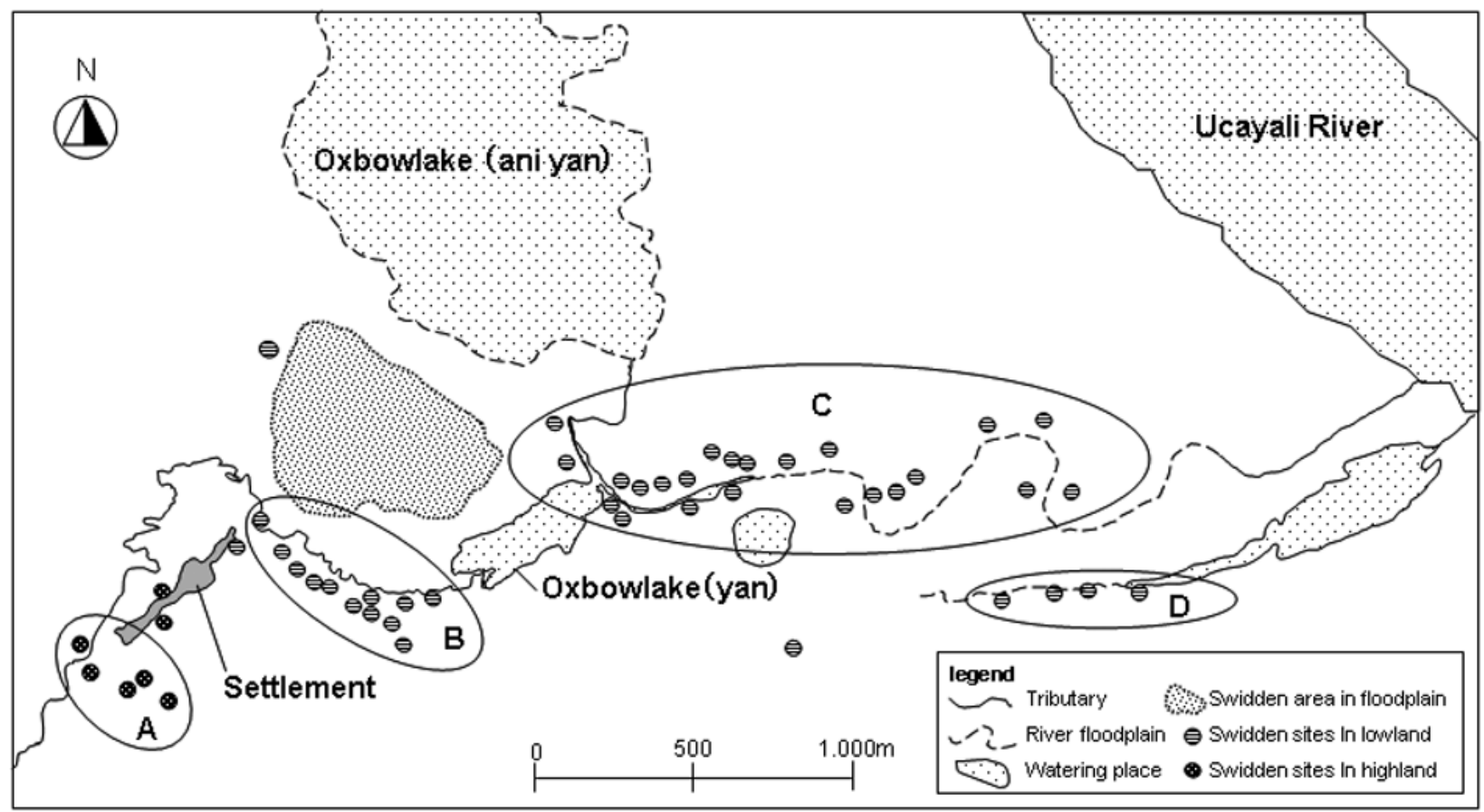

Fig.2. Map of the swidden sites of D Village in 2009.

Note 1: Locations of swidden sites principally were recorded by "Garmin 6OCSx" GPS receiver Some villagers were interviewed in order to gain complementary information to confirm locations. Source: Field Research

was the basic type, some village households are extended families, or grandparents with son or daughter and spouse, and some men live by themselves eating meals in other kitchens (households). Therefore, in this article a household is defined as a group of people eating together in the same house. According to this definition, D Village had 15 Shipibo households in November 2009.

Villagers often go to work away from home or visit relatives and friends in other villages, and being away from the village for some months is common. People from other villages also often come to D Village on a whim and stay for a while. In addition to movement between villages, villagers relocate their houses when rebuilding.

\section{Land classification and cultivation}

The Shipibo have their own land classification. When they open new land for swidden cultivation, they consider whether it is highland or lowland, and they have another

8 In the 1960 s, with the establishment of commercial rubber plantations, missionaries and the government built schools and clinics, and the Shipibo people gathered and formed bigger villages. In the 1970s, their residence pattern appeared to be strongly patrilocal (Hern 1976: 18). In the 1980 s, the nuclearization of families progressed and a researcher reported that no polygyny was observed in the villages along the main course of the Ucayali River (Hern 1992). important category for flood plains. From the interviewing and participatory observation in the village, it was disclosed that villagers categorize these three types of land as follows.

1) Flood plains (fene mapo nei): This land is usually flooded every rainy season. When the water level of the Ucayali River begins to fall and sand appears in the dry season, maize and rice are cultivated.

2) Lowlands (tasheba): Areas near rivers but not flooded in the rainy season. Around D Village, lowlands have not been flooded for more than 12 years. Bananas and cassava are popular crops cultivated here sometimes with maize. The villagers see that as long as they continue weeding, they can harvest bananas every year on this category of land. D Village has a history of only around 30 years, but there is a cultivated lowland field where harvests have continued for 15 years.

3) Highlands ( $n i)$ : Land far from the riverside, so soil erosion is rare even in heavy flooding in the rainy season.

9 The altitude of the boundaries between these land classifications was measured with a "Garmin 60CSx" GPS receiver in November 2009. In D Village, flood plains are above 162 meters above the sea level, lowlands are above 163 meters, and highlands are 171 meters or higher.

10 According to Hiraoka (1985), due to the supply of fertile soil with organic matter by seasonal floods, flood plains in the Peruvian Amazon provide sustainable harvests, and thus local people acquire surplus food. The Shipibo people also classify places for cultivation based on the quality of sand and clayey land (Behrens 1989). 
Some villager plant rice here, but most people cultivate bananas and cassava. People say that banana bunches become smaller around two years after staring a plantation. The village is situated on such land.

Flood plains are cultivated only in the dry season. The date and place where sand appears differ every year. After discovering exposed sand, the villagers start preparations for cultivating cash crops such as maize and rice. Both primary and secondary forests prevailing in lowlands and highlands are usually cleared at the end of the dry season (August), then bananas and cassava are planted, or maize is seeded. On land where maize is cultivated, bananas are planted as a part of mixed cropping before and after the maize harvest. Cassava can be harvested six months after planting, and it continues to be harvested for two years. After the harvest, land for swidden cultivation on highlands is abandoned on purpose. Cultivated fields on lowlands usually become secondary forests, but with weeding, they can be maintained as banana fields.

The rules for land use have not changed since the village was registered by the government as an indigenous community. Villagers used to open any part of the forest surrounding their settlements at will and use it for swidden cultivation. Although the forest is legally owned by the village, villagers clear land and make fields without permission from other villagers when that land is considered not to have been used beforehand. People who clear land are regarded as "owners (ibo)" of those areas, and crops harvested from the fields are considered to be the property of those villagers. Even after a field becomes a secondary forest, it is still recognized to be owned by the person who created it, and when someone else wants to cultivate it, the owner's permission is needed. But as explained below, when fields become secondary forests, crops and fruits found on/in the ground like bananas and cassavas are handled as "openaccess" resources meaning anyone can freely access to

11 According to Tournon (1988) Shipibo grows a mixed crop including banana in their swiddens. Not only Shipibo but also other linguistic groups also practice this type of swidden-fallow system (William 2002).

12 Bergman (1980) reported that in a Shipibo village that he had researched, bananas had been harvested for as long as 27 years on a highland plot. However, what he called "highland" was land right near the village and not usually affected by floods, where the local people were fond of practicing swidden cultivation (Bergman 1980). On checking his statements against the results of this study, land called "highland" by Bergman is "lowland" in this article (in D Village).

13 Individual villagers sometimes clear forest by themselves, but it is common to organize cooperative labor. Villagers usually do weeding when they visit their fields for harvesting. Bananas take nine months to be ready for harvest, and up to then the owners rarely visit the fields, leaving weeds growing thickly. As the harvesting seasons become near, owners arrange for cooperative labor to weed gardens all in one session. them. The land right of an owner is not permanent, and is cancelled when the owner stops working it. In other words, "ownership" for the Shipibo people is a kind of right for fields, or spaces where crops and fruit are cultivated, rather than for the land itself, and that right is legitimated by one,s continual use of the space.

\section{Changes in land reclamation}

This section explains the changes in land use and the expansion of cultivated fields in D Village with attention to the history of land reclamation. The places of cultivating fields were measured with GPS and other information was collected through interviewing.

In 1977 a settler came from the upper Ucayali River and built a house at the center of the current settlement and opened a cultivated field next to his house. After that two more men migrated there: one is a kinsman of the pioneer, who came from the same settlement where the settler had lived, and the other from a neighboring settlement created from cleared land. Both men built houses and made fields in the current settlement. Later, their close kin came to the village, but their dwellings were scattered instead of being concentrated in one place. In those days, villagers were criticized by those who live nearby if they did not start new fields. They thought that everyone should work to expand agricultural land so as to become self-sufficient, and a "ritual for making people into hard workers (rephuti)" was conducted daily for children who hesitated to help their parents. The distribution of food and invitations for meals were generally practiced among households. New immigrants in the settling phase grew maize and cassava preferentially because they grow quickly and can be harvested in a shorter period (three months, and four to five months respectively) than bananas (in the shortest, nine months). Before their fields became harvestable, they harvested crops from the first settler's fields or went to the nearest settlement 30 minutes away by canoe to request crop distribution. Land adjacent to dwellings was used for swidden cultivation. Land in the settlement interior was developed as farmland. In 1990 a villager purchased pigs and grazed them in the village. Because fields were located near the settlement, the pigs ate cassava and caused crop damage. Villagers stopped planting cassava near the village and opened new fields far from the village (see A and B in Fig. 2).

The village is located on the highland where floods

14 When villagers plant bananas on their fields, they are usually taller than $120 \mathrm{~cm}$ 


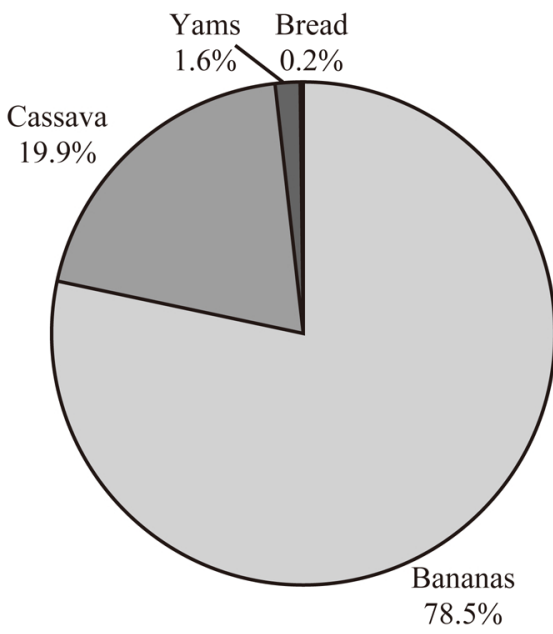

Frequency of foods as staple foods $(\mathrm{n}=1172)$

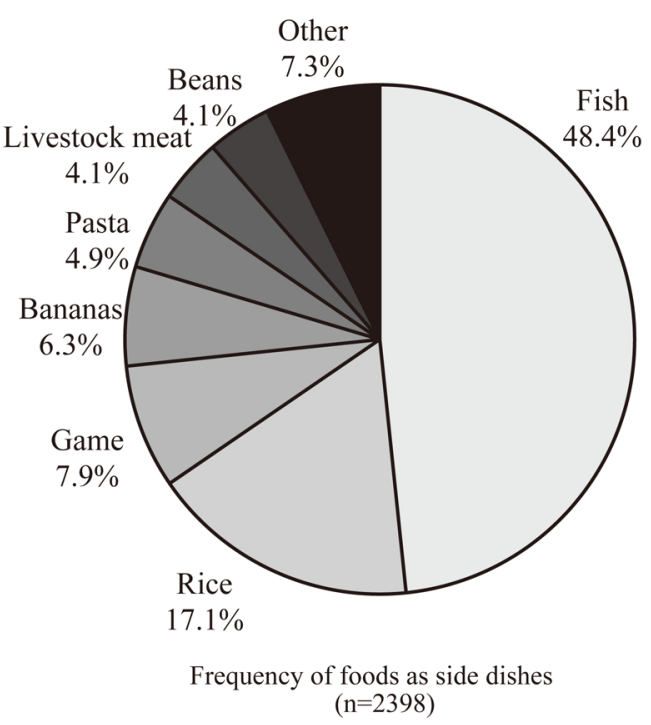

$(n=2398)$

Fig. 3. Frequencies of various foods in meals.

Note 1: The resarch was conducted from May 9 to May 28, 2009, from June 9 to June 29, 2009, and from July 6 to18, 2009. Thirteen household were selected, and women or household members who prepare meals were principally interviewed. Observations and interviews were conducted a total of over 1213 times.

Note 2: In the right-hand figure, the category "Others" includes canning fish (1.5\%), eggs $(0.7 \%)$, maize $(0.6 \%)$ shellfish $(0.6 \%)$, and cassava $(0.2 \%)$.

Note 3: Occasionally, villagers ate only a staple food or only a side dish. Also, they sometimes ate two or more side dishes together.

Source: Field Research

do not reach, but expectations for the continual harvest of bananas are not as great as in the lowland. In 2000 an old woman searched the lowland and cleared a swidden plot, which takes an hour to reach by foot and canoe from the village. Other villagers, mostly her lineage mates, followed her and opened the forest in the surrounding area (see $\mathrm{C}$ in Fig. 2). Around 2006 villagers made a unanimous decision to buy a head of cattle with proceeds from renting land to a logging company. Because it was grazed inside the village and ate banana suckers, villagers stopped maintaining banana fields around their houses. They tend to create fields in remote places (see C and D in Fig. 2), for which reason the banana fields inside the village were disused and had succeeded to secondary forests. In 2009 a cowshed was built far from the settlement and some villagers reopened fields near it. As shown in Fig. 2, the villagers' fields are distributed in a wide area, reflecting the history of changes in land reclamation.

\section{BANANA SHARING}

\section{Bananas in Shipibo meals}

In order to understand how the Shipibo use bananas, we checked how often each type of food was part of meals. Between May and July 2009, the first author selected 13 of the 15 village households and visited them twice a day to see what each household member prepared for meals. The author also performed participatory observations in the village and weighed bananas harvested by selected households. This research was conducted in the dry season going into the rainy season, and villagers explained that many bunches of banana, and the harvest amounts, increased around the time immediately after the rainy season (May and June), where as it decreased about the middle of the dry season in July. Villagers said there was no change in cassava harvest volume in the village because cassava is less affected by seasonal factors than bananas. As explained below, villagers deal with the seasonal fluctuation in the banana harvest by requesting distribution.

Results revealed that the basic meal in D Village is a combination of bananas and fish (Fig. 3). Bananas were more often part of meals than was cassava. Yams and bread were sometimes eaten, but they were light meals to the villagers, and were seldom eaten as part of regular meals. Fish was the most common main dish. Indeed, the elders said, "We eat rice when there is no fish (pitiuma, noa arrosh piei)." Other foods besides fish in meals included game obtained by hunting, livestock meat, pasta, and rice. However, villagers say, "We cannot eat fish

15 Bananas weighed included those thought to have been harvested from different fields.

16 Rice consumed in D Village is harvested from villagers' fields, purchased at the settlement kiosk or city market, and rice supplied by the government. 


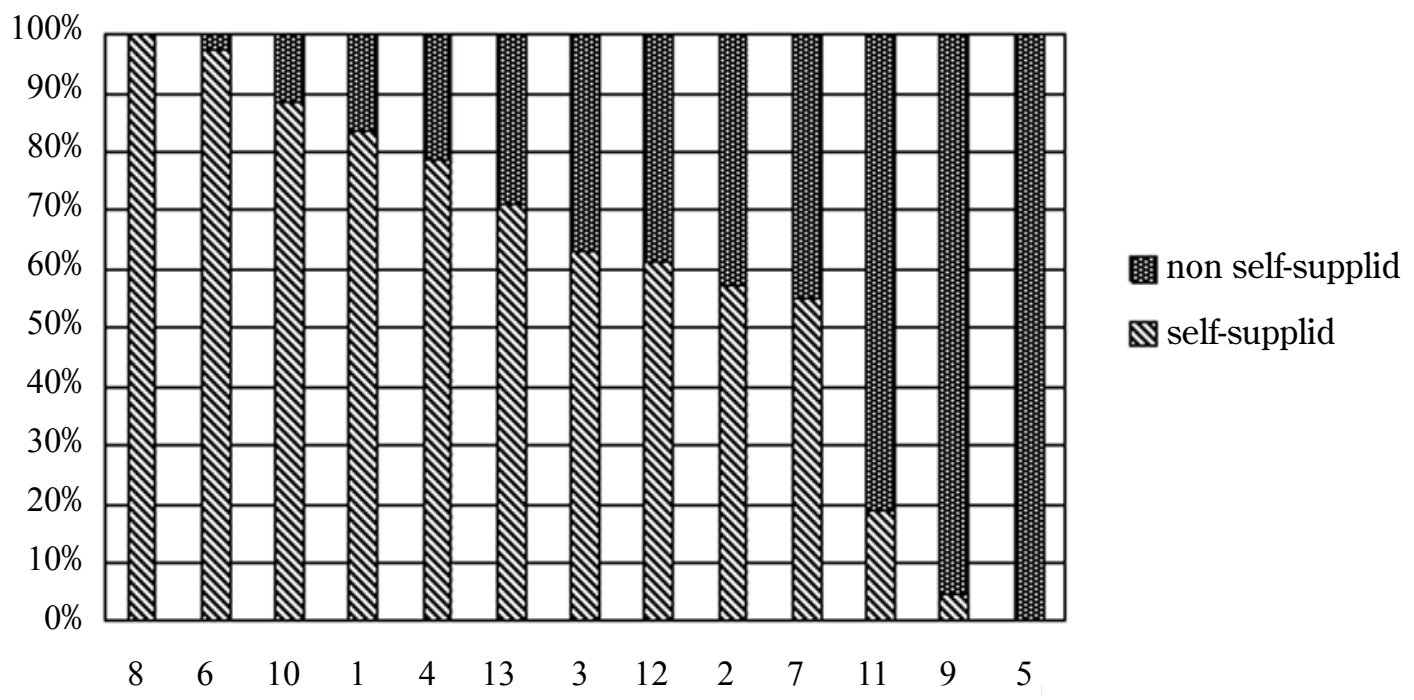

Household number

Fig. 4. Self-sufficiency rate, for bananas in meals in each household ( $\mathrm{n}=913)$.

Note 1: When a household cooked and mixed bananas self-supplid by its members and bananas asquired from other households, both examples werw counted by 0.5 . But such instances were odseryed only 11 times.

Note 2: Because ahouoohold member worked for a timber protiuclion operation, household 6 was researched from May 6 to 29 and from July 6 to 18 , 2009 , for a total of 37days.

Source: Field Research.

without bananas (parantauma piti piyamai)." Bananas are consumed every day, and they are an essential part of the villagers' diet.

\section{Banana use}

Usually the villagers go to harvest bananas with household members. Households that have fields near their houses (see B in Fig. 2) harvest bananas almost every day, while households that planted bananas far from the village (see C or D in Fig. 2) visited their fields every several days. Sometimes a villager would harvest more than 30 bunches. Bananas are stored on the second floor of the kitchen. As days pass, bananas ripen and turn from green to yellow.

Villagers think that more than 20 banana species are used. Only a few species are eaten raw for their special taste, while there are no differences in the way the others are used. The villagers eat bananas raw as a snack, but children who have loose bowels are kept from eating too many raw bananas. Usually, bananas are cooked before they become yellow. Specifically they are boiled (joa), stewed with fish (neni), or grilled (xoi). Yellow bananas are cooked into juice.

\section{Non-self-sufficiency in bananas}

In D Village it is said that "a Shipibo old man, first of all, must construct a house and cultivate a field." Whereas villagers receive bananas from others in connection with "sharing," they are expected to produce bananas themselves. Figure 4 shows rates of self-sufficiency (and non-self-sufficiency) in bananas cooked as staple foods in 13 households. Only one household was self-sufficient. Ten households grew more than half of bananas they consumed. On the other hand, three households did not produce more than half of the bananas they themselves consumed, with the bananas supplied by other households accounting for more than four-fifths of their consumption. Household 11 is that of a person who had recently returned to the village and had no harvestable field, and household 9 used the field of his parents, who did not live together. Most D Village households eat a certain portion of bananas that were supplied by other households.

\section{ACQUISITION OF BANANAS FROM OUTSIDE THE HOUSEHOLD}

This section explains how villagers obtain bananas from 
outside their households. Apart from self-support, the acquisition of bananas from other households is classified as the acquisition of post-harvest bananas from other households in the village and the direct acquisition of bananas from the fields of other households. Both types are explained in detail below using cases.

\section{Acquisition from other households in the village}

Villagers obtain post-harvest bananas in the village through requests, as gifts, as requitals (for borrowing something)/exchanges, and through purchase (Table 1).

1) Request (yokati): This means the acquisition of bananas by asking other households for them. When the stock of bananas in the kitchen runs out, villagers visit other households and say, "Please give me bananas (paranta menie)." The person who goes to ask is a woman responsible for cooking or a child sent by their mother or other adults. When one has bananas at home and is asked for them by somebody, they must be given as part of distribution. During the 62 days of the research, this was done 129 times.

2) Gifts (menirsa): When bananas are given by one person to another without a request, it is a gift. Such distribution occurred 37 times during the same period. Household 13 acquired the largest amount of bananas in the village (Table 2 ). This was because a new village school teacher stayed there, and several villagers gave gifts for him as a sign of respect/welcome. In the case of household 11, bananas were gifted to them because they had recently returned to the village and had no field. A common reason for gifts is the presence of visitors from other villages, such as close relatives.

3) Requital (menirsa)/exchanges (cambio): For example, when one returns a dish to its owner with which fish had been given (gifted), bananas will be put on the dish as a requital. In contrast with gift-giving explained below, a requital is conducted with a clear idea of a favor owed and the intention of a gift in return. For example, a villager presents bananas to another villager simply because the latter gave the former bananas or other food beforehand. In contrast to requital, exchange means strategically

Table 1. Weight of bananas according to interactions in D Village.

\begin{tabular}{|c|c|c|c|c|c|c|c|c|c|c|c|c|}
\hline \multirow[b]{3}{*}{$\begin{array}{l}\text { House- } \\
\text { hold } \\
\text { number }\end{array}$} & \multirow{3}{*}{$\begin{array}{l}\text { Consump- } \\
\text { tion for } \\
\text { household } \\
(\mathrm{kg})\end{array}$} & \multirow[b]{3}{*}{$\begin{array}{l}\text { Supply to } \\
\text { others } \\
(\mathrm{kg})\end{array}$} & \multirow{3}{*}{$\begin{array}{l}\text { Acquisi- } \\
\text { tion from } \\
\text { others } \\
(\mathrm{kg})\end{array}$} & \multicolumn{4}{|c|}{ Post-harvest in settlment } & \multicolumn{5}{|c|}{ Harvests from other households' fields } \\
\hline & & & & \multirow{2}{*}{$\begin{array}{l}\text { Requests } \\
(\mathrm{kg})\end{array}$} & \multirow[b]{2}{*}{$\begin{array}{l}\text { Gifts } \\
(\mathrm{kg})\end{array}$} & \multirow[b]{2}{*}{$\begin{array}{l}\text { Requital } \\
\text { and ex- } \\
\text { change } \\
(\mathrm{kg})\end{array}$} & \multirow[b]{2}{*}{$\begin{array}{c}\text { Purchas- } \\
\text { es } \\
\text { (kg) }\end{array}$} & \multicolumn{2}{|c|}{$\begin{array}{c}\text { Harvests permitted } \\
\text { by owners }\end{array}$} & \multicolumn{3}{|c|}{ Tacit-permission harvests } \\
\hline & & & & & & & & $\begin{array}{l}\text { Requests } \\
\quad(\mathrm{kg})\end{array}$ & $\begin{array}{l}\text { Gifts } \\
(\mathrm{kg})\end{array}$ & $\begin{array}{c}\text { Close kin } \\
\text { of owners } \\
(\mathrm{kg})\end{array}$ & $\begin{array}{c}\text { Field } \\
\text { looks like } \\
\text { secondary } \\
\text { forest (kg) }\end{array}$ & $\begin{array}{c}\text { Owner is } \\
\text { absent } \\
(\mathrm{kg})\end{array}$ \\
\hline 1 & 1063.2 & 201.0 & 52.0 & 32.4 & 12.6 & 7.1 & 0.0 & 0.0 & 0.0 & 0.0 & 0.0 & 0.0 \\
\hline 2 & 538.0 & 70.5 & 91.6 & 24.3 & 8.2 & 0.0 & 0.0 & 12.4 & 12.4 & 0.0 & 11.5 & 22.8 \\
\hline 3 & 942.2 & 112.0 & 191.1 & 64.9 & 63.2 & 0.0 & 0.0 & 0.0 & 24.8 & 15.6 & 9.7 & 1.9 \\
\hline 4 & 1152.7 & 152.3 & 89.7 & 15.1 & 22.3 & 0.0 & 0.0 & 56.3 & 0.0 & 0.0 & 0.0 & 0.0 \\
\hline 5 & 672.0 & 7.6 & 629.7 & 170.0 & 15.7 & 11.0 & 12.9 & 114.7 & 0.0 & 0.0 & 35.9 & 269.5 \\
\hline 6 & 245.9 & 251.4 & 4.4 & 4.4 & 0.0 & 0.0 & 0.0 & 0.0 & 0.0 & 0.0 & 0.0 & 0.0 \\
\hline 7 & 657.8 & 3.0 & 220.5 & 72.2 & 4.4 & 0.0 & 0.0 & 55.8 & 52.9 & 12.9 & 0.0 & 22.3 \\
\hline 8 & 1596.9 & 495.7 & 0.0 & 0.0 & 0.0 & 0.0 & 0.0 & 0.0 & 0.0 & 0.0 & 0.0 & 0.0 \\
\hline 9 & 368.1 & 55.1 & 410.8 & 18.0 & 4.0 & 1.5 & 0.0 & 0.0 & 18.0 & 369.4 & 0.0 & 0.0 \\
\hline 10 & 544.8 & 25.9 & 22.4 & 12.0 & 0.0 & 0.0 & 0.0 & 0.0 & 0.0 & 10.4 & 0.0 & 0.0 \\
\hline 11 & 374.9 & 27.1 & 217.3 & 42.2 & 68.6 & 0.0 & 0.0 & 42.5 & 38.5 & 12.5 & 0.0 & 13.1 \\
\hline 12 & 347.3 & 43.2 & 19.4 & 12.0 & 7.4 & 0.0 & 0.0 & 0.0 & 0.0 & 0.0 & 0.0 & 0.0 \\
\hline 13 & 619.7 & 0.0 & 140.8 & 38.9 & 98.2 & 0.8 & 0.0 & 0.0 & 0.0 & 0.0 & 0.0 & 3.0 \\
\hline
\end{tabular}

Note 1: The research was conducted from May 9 to 29, and June 8 to July 18, 2009, 62 days in total. Since a member of household 6 was working for a timber production operation, that household was researched from May 9 to 29, and from June 20 to July 18, 2009, for a total of 50 days.

Note 2: In this table, weight the banana skin. Primarily, bananas were weighed by a spring balance and scale with a 10-g capacity. Some bananas were measured by sight estimation. The first author calculated average weights of bananas harvested from each field based on a sample of weighed bananas. The edible portion of bananas in this area is $47.2 \%$.

Note 3: Generally speaking, the unit of banana distribution and acquisition in the village is a "hand," while it is a "bunch" when acquired from others' fields. Note 4: In this table, harvests from fields whose owners were not absent from the village were categorized under "owner is absent" because the harvesters did not tell from which farms they harvested bananas. On the other hand, the category "Supply to others" was allowed with the permission of the owners or close kinship with the owners.

Source: Field Research 
Table 2. Banana acquisition in household 5.

\begin{tabular}{|c|c|c|c|c|c|}
\hline Dates & Requesters & $\begin{array}{l}\text { Who gives } \\
\text { bananas } \\
\text { (Household) }\end{array}$ & $\begin{array}{l}\text { Manner of } \\
\text { acquisition }\end{array}$ & $\begin{array}{l}\text { Amount } \\
(\mathrm{kg})\end{array}$ & Notes \\
\hline \multirow[t]{2}{*}{ 14-Jun } & $\mathrm{Cm}$ & 2 & Request & 2.2 & Visited the house for request. \\
\hline & $\mathrm{s} / \mathrm{n}$ & 1 & Request & 2.2 & \\
\hline 16-Jun & $\mathrm{Cm} \cdot \mathrm{Cf}$ & $\mathrm{s} / \mathrm{n}$ & $\begin{array}{l}\text { Harvest without } \\
\text { permission }\end{array}$ & 9.16 & From someone's field \\
\hline 19-Jun & W & 2 & Request & 1.8 & $\begin{array}{l}\text { When the wife of household } 2 \text { asked household } 5 \text { for fish, W } \\
\text { asked for bananas. }\end{array}$ \\
\hline 20-Jun & - & 10 & Requital & 2 & $\begin{array}{l}\text { Given when household } 10 \text { returned a dish with which they } \\
\text { had received fish from household } 5 \text {. }\end{array}$ \\
\hline 21-Jun & - & 4 & Requital & 3 & $\begin{array}{l}\text { Given when household } 4 \text { returned a dish with which they had } \\
\text { received fish from household } 5 \text {. }\end{array}$ \\
\hline 21-Jun & - & 1 & Requital & 3 & $\begin{array}{l}\text { Given when household } 1 \text { returned a dish with which they had } \\
\text { received fish from household } 5 \text {. }\end{array}$ \\
\hline 22-Jun & $\mathrm{W} \cdot \mathrm{C}$ & 13 & Request & 1.2 & Stopped and asked the wife on thier way home. \\
\hline 23-Jun & $\mathrm{Cm} \cdot \mathrm{Cf}$ & 6 & Request to harvest & 85.5 & \\
\hline 26-Jun & $\mathrm{W}$ & 13 & Request & 3.3 & Stopped and asked the wife on her way home. \\
\hline 29-Jun & W & $\mathrm{s} / \mathrm{n}$ & $\begin{array}{l}\text { Harvest without } \\
\text { permission }\end{array}$ & 2.4 & From someone's field \\
\hline \multirow[t]{2}{*}{ 1-Jul } & $\mathrm{Am}$ & 8 & Request & 4.4 & Saying, "I want my mother to eat bananas." \\
\hline & $\mathrm{Cm}$ & 8 & Request & 2.4 & Stopped and asked the wife on his way home. \\
\hline \multirow[t]{2}{*}{ 2-Jul } & $\mathrm{Cf}$ & 4 & Request & 2.7 & \\
\hline & $\mathrm{Bm} \cdot \mathrm{Bf}$ & $\mathrm{s} / \mathrm{n}$ & $\begin{array}{l}\text { Harvest without } \\
\text { permission }\end{array}$ & 51.9 & From someone's field \\
\hline 6-Jul & $\mathrm{Cm}$ & 4 & Request & 2.5 & \\
\hline 7-Jul & $\mathrm{W} \cdot \mathrm{C}$ & 7 & Gift of harvest & 33 & Invited for the harvest in the field of P's father, who had died. \\
\hline \multirow[t]{2}{*}{ 11-Jul } & $\mathrm{W} \cdot \mathrm{C}$ & 14 & Request & 3 & $\begin{array}{l}\text { On their way home, } \mathrm{W} \text { and } \mathrm{C} \text { asked a child of the household } \\
14 \text {, because the wife of the household was sleeping. }\end{array}$ \\
\hline & $\mathrm{Am}$ & 1 & Request & 4 & \\
\hline 13-Jul & $\mathrm{Bm} \cdot \mathrm{Cf}$ & 8 & Request & 130.5 & Cm's mather is a sister of the wife living in household 8 . \\
\hline
\end{tabular}

Note 1: Information was collected from June 14 to July 13, 2009 by infomal interviews and participatory observation.

Note 2: Household 5 comprised a husband, his wife $\mathrm{W}$, their child $\mathrm{C}$, and three adult kin couples (Am \& Af, Bm \& Bf, and Cm \& Cf).

Note 3: From July 2nd to 5th, 2010 the husband, his wife and child, and two of the couples (Am \& Af and Bm \& Bf) was absent in the D Village for visiting other community.

Note 4: Concerning the weight of bananas, see Note 2 in Table 1.

Note 5: P stayed at household 7. She previously had lived in D Village. She traveled between another village and D Village.

Source: Field Research

giving food like fish to someone so as to receive bananas from that person in return. Such transfers of bananas were observed 14 times.

4) Purchase (marti): Purchase means an exchange of cash for bananas. This was observed only once. A person concerned stayed in household 5 , but he had just come to D Village from another village for the purpose of cultivating cash crops. He offered to purchase bananas while holding cash in one hand.

As seen in terms of how often bananas were part of meals (Fig. 4), only household 8 was self-sufficient in bananas (Table 1). This household gave away more bananas than did any other household, and that amount was equal to one-third of its home consumption. Only household 13 gave no bananas to anyone else, while on the other hand household of 6 gave more bananas to other households than were consumed at home.

\section{Banana exchange relationships in the village}

In terms of weight, request was the most popular method in D Village to acquire bananas. Two sociograms below

17 Rates of self-sufficiency differ between evaluations by the number of times bananas are included in meals (Fig. 3), and by evaluation by weight. (Table 1). This difference occurs because the former reflects how many times bananas were cooked for meals, while the latter includes all banana usage, not only meals but also for juice and as snack food. This discrepancy suggests that households which were not able to harvest every day requested green cooking bananas from other households, while most bananas used for juice are self-supplied. 


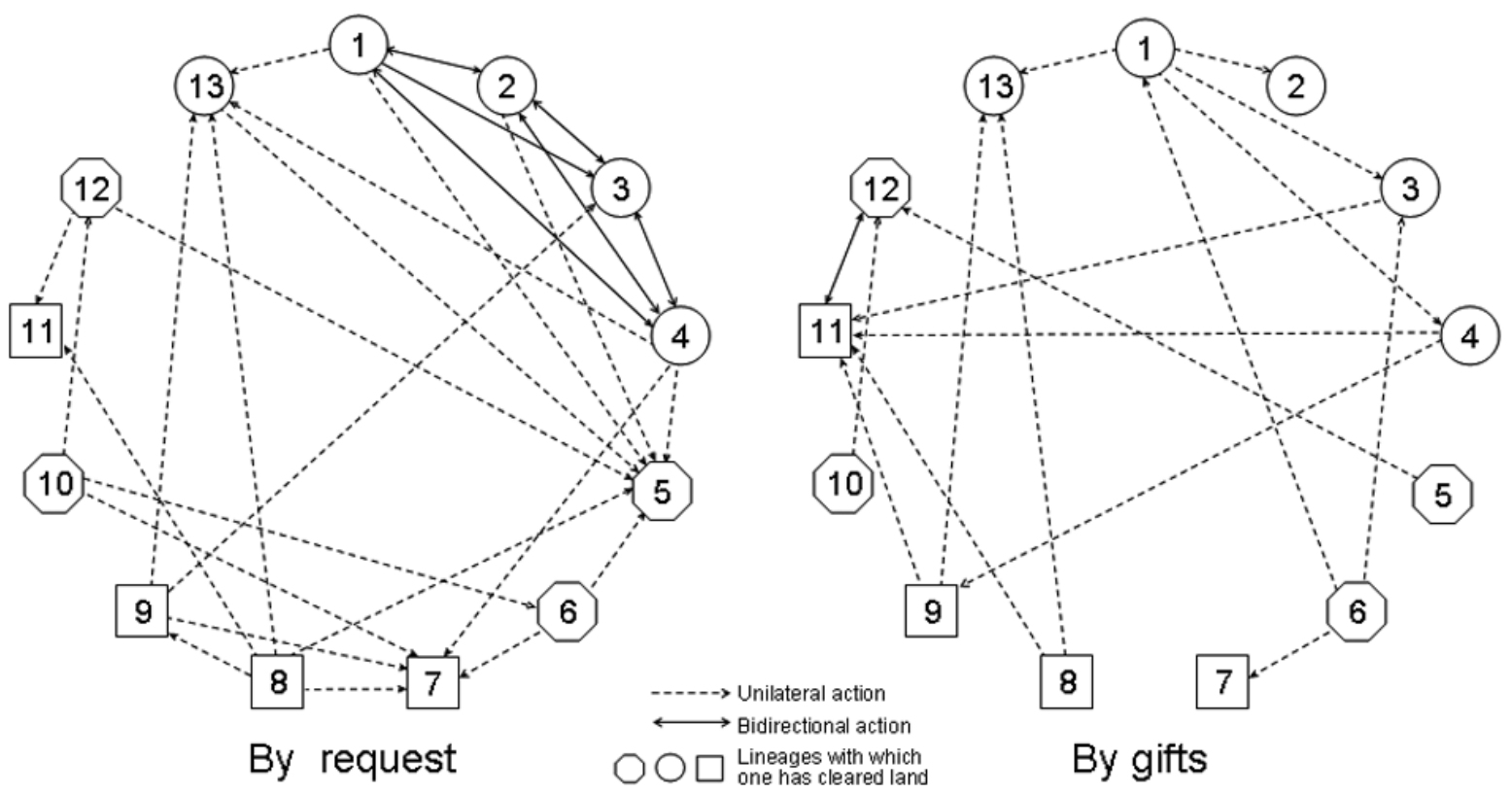

Fig. 5. Sociograms of banana distribution in the $\mathrm{D}$ village.

Note 1: The resaerch was conducted from May 9 to 29 and from June 8 to July 18, 2009, for a total of 62 days. Since a member of household 6 was working for a timber production company, the household was researched from May 9 to 29 and from June 20 to July 18, 2009, for a total of 50 days.

Note 2: Lineages are basic ally cate gorized by matrilocal residenses. Yet, households 3, 7, 9, 11, and 13 have patrilocal residences, because the wives of 3, 11, and 13 had migrated from other communities 7 and 9 manied villagers, 7 lives patrilocally, and 9 lives near the house of his father in the lowland. Source: Field Research.

express the relationships among households in the village (Fig. 5): those which provided bananas to those which made requests, or those which gave bananas as gifts.

In this sociogram, we can see how all households participate in the village "sharing" system by asking for and receiving gifts of bananas, by receiving requests, and by giving gifts. Requests come more through unilateral action than through bidirectional action. Wives and others in charge of cooking in households 5, 7, and 11 received bananas unilaterally from different households, but they receive no requests from other households. On the other hand, wives and others in charge of cooking in households 8 and 10 received requests from several households, but made no requests to others. We can see that bidirectional actions occurred among households 1, 2,3 , and 4 . They asked each other for bananas when they had none in their own kitchens. They share the same lineage. Both requests and gifts were made unilaterally rather than bidirectionally, and also when there were requests.

Compared to requests, opportunities for gifts were limited, and during the field observations, a mutual gift occurred only between households 11 and 12 . It is not clear whether gifts were given on the basis of lineage, but household 1 harvested many bananas at one time and gifted them only to households of the same lineage $(2,3$,
$4,13)$ when they came to household 1 . This is because the Shipibo are supposed to gift abundant food to visitors who come calling. Household 11, whose members were a husband having returned to his native village, a wife from the outside, and a single man of different lineage from the husband, had a low rate of self-sufficiency. They were gifted by as many as five households, and their ratio of gifted bananas to that of domestic consumption in terms of weight is the highest in the village (Table 1). Even after sedentalisation, the Shipibo people have kept their mobility and custom of actively offering bananas to returners and newcomers.

\section{Permitting harvests from other households' fields}

In addition to asking for the distribution of bananas that have already harvested in the village, villagers often harvest bananas by themselves from others' fields. This is done both 1) with the owner's permission and 2) without permission. Permission is given by asking an owner (for permission) or as an invitation by the owner to go together and harvest bananas from the owner's field. Even without permission, villagers harvest bananas from the cultivated land of someone else if the owners are close kin, if the land has become secondary forest, or if the owners are absent from the village. 
1) Harvest request: This is when people ask field owners if they may harvest bananas there and get permission. Villagers whose fields are far from villages commonly ask to harvest on others, fields near the settlement when they cannot visit their own fields because of rain, or when their own bananas are not ready for harvest. In Table 1, the households 6 and 8 provided a certain amount of bananas to other households because they were often asked permission to harvest on their lands due to their closeness (see B in Fig. 2), while the other households, fields are farther away (see C and D, Fig. 2).

2) Harvest gift: This is when the owner of a field or persons who are permitted by the owner to enter that field offer an invitation by saying, "Let's go harvesting (caecanen paranta bi)" or "You may harvest (paranta bie)." Those who receive such invitations may harvest bananas. In villagers, daily conversation, owners invite or allow members of other households to receive this harvest gift because many bananas are ripe, or the owner knows who does not have harvestable bananas at that time.

\section{Tacit-permission harvests from other households' fields}

In this article, tacit-permission harvest means that field owners do not know whether others have harvested bananas from their fields. In D Village, this kind of harvesting is considered legitimate under the following conditions.

1) Close kinship with owners: One can harvest bananas without the owner's permission if the owner is one's farther or brother living in different households. Household 9 had no land with harvestable fruit, but they got bananas freely from the land of household 8 , the parents of the husband of household 9. In other examples, the wife of household 7 harvested bananas from her father's field (household 6), and household 10 harvested from the field of household 12 because their wives are sisters. Therefore while production and consumption are practiced on the household, or nuclear family, harvesting bananas without asking permission on other households' land is practiced even after a person marries and becomes a new production/consumption unit as long as one has close kinship ties with the household of the landowner.

2) Land looks like a secondary forest: When a field is abandoned after harvesting bananas, it becomes a secondary forest. If a villager opens a plot in a secondary forest, that land is regarded to be that person,s property, and bananas found on such a land are accordingly regarded as the owner,s property. However, since owners seldom visit their cultivated fields when they become near-secondary forest, anyone passing through may harvest bananas found there. Those bananas are called "naw paranta (forest bananas)."

3) Bananas in absentee,s field are for cutting and taking: Elders said, "Bananas in absentee,s field are for cutting and taking (iboma paranta xatoti)." One may harvest bananas from a field whose owner is working far from home and absent. Since bananas are just wasted if they are not harvested when ripe because the owner is absent, villagers think that giving is better than wasting. Regarding the waste of bananas in that way, the people say, "Bananas will rot, we give to others [rather than let them rot in the field] (paranta menit, nato payoticai)." As shown in the Table 1, in D Village this means of securing bananas is used mostly by household 5 .

\section{"LAZY" PEOPLE IN SHIPIBO SHARING}

\section{Indigenous concept for food distribution}

In the Shipibo language, "yiati" means "have" or "exist." As explained above, the owner of bananas harvested from a plot of land is clearly defined. When those who do not "have" request bananas from those who do, the bananas are given simply because "they do not have (bananas)." A person who begrudges something when requested is criticized as "yoashi." Villagers explain that "yoashi" means "to have but not give (haya ikashu muniyama)" or "a fist clenched tightly (meken churish)," suggesting "yoashi" means both a stingy person and to be stingy. Villagers fear being regarded as "yoashi" because they think such persons become the target of black magic owing to bitter feelings. Banana distribution in the village is conducted not from the fear of being seen as "yoashi," but from the general perception that there is nothing unusual in giving bananas when requested. However, a discrepancy in perceptions concerning banana distribution is arising among villagers. This chapter explains how banana exchange among some villagers has stopped by describing in detail the interactions and statements by involved villagers.

18 When villagers decide to leave their village but still have parents, children, or brothers in the village, they usually yield their field rights to them.

19 Stocks (1996) suggested that in Cocamilla society, another linguistic group in this area, "stinginess" in their food distribution is "a powerful push factor" which make someone to migrate. 


\section{A person without field is "lazy"}

As explained above, in the village it is said that bananas in an absentee,s field are for cutting and taking. Since 2007 the tacit-permission harvest of bananas has happened even when the landowners were in the village. Villagers call this kind of harvesting without permission "stealing (yometsu)." Formerly when villagers wanted to harvest bananas from others, land, they would always ask the landowner for permission. An elder said, "They steal bananas because they do not have their own fields. The reason they have no fields is because they are 'chiquish (lazy person/to be lazy)'."

Other villagers also say that their bananas are "stolen," when someone takes bananas from their land without asking. If it happens in a field far from the village and near the Ucayali River, villagers say among themselves that outsiders like the mestizo stole the bananas. When bananas have been stolen from cultivated fields near the village, the discoverers or victims tell other villagers about it using a loudspeaker, but no one talks openly about it or suggests who the thief is. While villagers never try to identify the guilty person in public, they often say that person is "chiquish," expressing it thus: Because that person is "chiquish," they need to steal bananas. However, "chiquish" is not only a term of criticism, but also a joke in daily conversation. When villagers are not keen to work, they will laugh and say, "Now I am being "lazy" (ea chiquisha)." "Chiquish" carries a wider range of meaning than "yoashi," but nowadays discord among villagers seems to be increasing over "chiquish" who do not make their own banana fields. As explained above, newcomers and returners are not considered "chiquish" and are counted among those who receive bananas. The village has one household which has not tilled its own fields except a cassava field for a long time and has kept asking other households for bananas. They have succeeded in obtaining bananas, but recently their requests are being refused. Following is a description of the current situation in which bananas are no longer given when requested.

\section{A "Lazy" person is dropped from a circle of "Sharing" \\ Opinion on the side of a "lazy" person}

At the time of our field research, household 5 comprised eight adults and one child, including the wife (W) and child of the household owner, who was usually in the village, and three married couples which included three children of the owner. One of the three couples was living in the household temporarily in order to cultivate cash crops. The other two couples were registered as residents of D Village and another village, and moved between two villages. This household have planted bananas randomly in the cassava fields, and used banana fields of W's uncle and brothers. However, her kin ship members moved out from the village in 2004 and her father followed them in around 2005. After that they have not opened their banana fields although these fields had already changed to secondary forest. Instead continuing to request the distribution of bananas or permission to harvest them from other households' fields. In general, requesting distribution or harvest permission is women's work, and sometimes children are ordered by their parents to play that role. Contrary to this, all the members of household 5 but their husband made such requests (Table 2). Usually, many children and their parents of household 5 are absent because they visit and stay at other villages. However, about an anniversary of the village (second May), all member of the household 5 stayed at the village in order to cultivate cash crop or to join an anniversary of the village. They aggressively requested bananas to other households. On July 1, different members of household 5 visited the same household to get bananas. When asking for bananas, they emphasized such facts as "My mother wants ripe bananas (nokon tita paranta picasei), or said that the field owner is an aunt asking. Villagers usually decide to ask other households for bananas after they find or confirm that their own households are out of bananas. Yet, the members of household 5 request distribution when they pass by others households, without knowing for sure if their household has bananas or not (see June 6, July 2 and 11, in Table 2).

When asked by the first author her opinion on continuing requests for distribution, the wife (W) answered, "Bananas are cheap, so asking for them is no problem," and "One should not be a 'yoashi' when someone asks for bananas," taking for granted that D Villagers will share bananas with her household.

\section{Statements by those who were asked for bananas}

Y (male), living in the household 6, is a villager who has been often asked for bananas by $\mathrm{W}$, the wife of household 5. He said, "The father of W, had a cassava field, but had not started a banana field. That family has been asking for bananas since her father's generation. 'Chiquish' runs in the family. But, in her household, the husband is 'good (jakhun).' My niece (W) has a character fault. Well, her 
(W's) son also 'money stomach (criki puku)"' (May 28, 2009). In the village, money stomach is meaning to love money.

One day the first author talked to Y's daughter U (household 7) and her little sister in the kitchen of household 6. U lives in a different household from Y, but she (U) freely uses the kitchen of her father's household. At that time a member of the household 5, Cm (male), came to ask for bananas. He wanted to exchange fish for bananas, saying, "A fisher gave us lots of fish, and there are lots of them left. So, I want to exchange them for bananas." After $\mathrm{Cm}$ had received bananas and left, U looked at her sister and muttered, "I am tired [of responding to their requests] (Pashukin)." Cm returned with fish for Y later, but $U$ was gone (May 27, 2009). The people in household 5 wanted to exchange fish or bush meat for bananas, and sometimes the food they presented was not fresh but the small and worthless like fish that fishers gave away. Before the decrease in fishery resources because of commercial fisheries near the village, they used to distribute what they fished aggressively, but now the obtainable volume of fish was declined.

L (female, household 1), who belongs to another lineage with Y, has long been asked to share bananas with W. On July 12, 2009, when she saw W approaching her house, she shouted to her children, "W is coming! If she asks if we have bananas, just say 'no,' because W 'does not care for others (shinnayama).' Several days ago, W was drunk and engineered a quarrel with $\mathrm{L}$. Then W cried "You sleep with my husband." After that, L stopped giving bananas to W. A few days later, her husband climbed up to the loft and hid bananas, as L stood in plain sight where anyone asking for bananas can see her giving instructions from the kitchen: "Just a little more inside, inside" (July 14, 2009). From this day, they stopped giving bananas. A big sister of $\mathrm{L}$ also hind bananas to a stockroom, and she also avoided distribution. Knowing their behavior, Y said "Those who do not give 'chiquish' bananas are not 'yoashi,' even if they have bananas (Haya ikash muniyama, jabira yoashima chiquish jacopi)" (July 17, 2009). Y admitted that he would not like to give bananas to them anymore, saying, "I used to often invite $\mathrm{W}$ to harvest in my fields, but I don't do it now."

L, her household members, and her sister's household members avoid distribution first by hiding their bananas. If it is found that they have bananas but are hiding them so as to avoid distribution, they would be considered "yoashi." However, the understanding of Y and $\mathrm{L}$ is that because those who repeatedly ask for bananas are "chiquish" who "do not care for others," keeping their bananas and refusing distribution is not "yoashi."

\section{DISCUSSION}

\section{How bananas are distributed}

In the preceding discussion, the Shipibo are said to exchange bananas among kin (Bergman 1980), and their exchanging bananas when there is a surplus is seen as a risk-aversion system (Behrens 1992). However, in D Village bananas are distributed at such times as when there is no obvious surplus, and beyond one's lineage. In addition, the exchange is not an activity restricted to inside the settlement, as D Villagers distribute and receive bananas outside the settlement, on their fields, and sometimes without the permission or realization of field owners. Whereas the residential pattern has changed from the customary one based on the extended family to one based on the nuclear family, many people use their close kin's fields to harvest the bananas freely. Thus field use goes beyond the members of the owner's household. Requests for bananas are made more frequently among lineage-mates or close kin, such as father-son or between brothers. However, the exchange of bananas in D Village includes other various types that are not related to lineage, such as requests from those whose fields are far from the village to those who have cultivated land near the village, gifts to visitors as a sign of welcome, and bananas given to returners without fields ready for harvest. Therefore the "sharing" of bananas in Shipibo society includes both kin-based and non-kinbased relationships with various distribution practices in the pre- and post-harvest phases.

\section{Active distribution to newcomers and "lazy" persons harvest without permission}

In Shipibo society, bananas have been distributed by those with bananas in their fields to people with fields but no harvestable bananas. The current situation, in which many villagers give free bananas to people who have returned to the village from migrant work, is similar to that of the pioneering days when new immigrants asked for and received bananas from the Shipibo people in neighboring villages. As a custom of the Shipibo, a migratory people without permanent villages and sedentary lifestyles (Hern 2003), reciprocal practice has 
been practiced so far (Behrens 1992). Beforehand, such a custom was conducted just among kinship members who live nearby (Roe 1980), but as the government began to register administrative villages, the Shipibo sedentarized and lived together with non-kin people, and the food distribution came to be practiced even between kin and non-kin relations. Bananas are distributed to a household which have been in the village several years but have not started its own fields. Besides such a customary distribution of bananas, a notion that a villager can harvest food from others' fields without permission, which is based on the nature of bananas to rot quickly after ripen, enables a "lazy" person to be a free-rider who gets food without banana cultivation. Compared with newcomers and returners, a free-rider utilizes this notion more in order to get bananas from others. Behrens (1992) considered the banana distribution in the Shipibo society to be a social safety-net, but it has a negative side of bringing about a free-rider and results in provoking villagers' complaints and dissatisfaction.

\section{Exclude free-riders from the circle of "sharing"}

As the Shipibo people consider "sharing" to be important and a person rejecting it is condemned as "yoashi," villagers followed the custom and continued to give bananas even to a household which do not give (back) to others. While that household is complained of and condemned as "chiquish," they used to give unconsumed fish in exchange for bananas. However, the decrease in fishery resources in the river makes them to ask to other villagers one-sidedly. It means that the influence from the outside played a certain role in their becoming "chiquish."

As driven into such a situation, this household took strategic advantage of the general norm in the village that legitimate their claims and obligates others to offer them food. Also, household members were quick to find opportunities to obtain bananas, and tried to acquire bananas whenever such opportunities arose. Villagers who received frequent requests became dissatisfied despite their ingrained social behavior, but continued to give bananas. However, as a result of accumulated discontent through repeated interaction, when a person stopped distribution though the reason was personal, other persons followed refusing the requests. They came to maintain that to refuse such requests and hiding bananas is not a sign of being "yoashi," if the person requesting bananas lacks "shinna (care for others)."

"Yoashi" have been blamed in the Shipibo society because their behavior seemed to lack "care for others." However, as the extent of free-riding by "chiquish" escalated, they legitimated their behaviour to "chiquish" that used to be regarded as a sign of "yoashi" by pointing out that they ("chiquish") lack "shinna (care for others)." This result demonstrates that the very reasoning which has encouraged the distribution between the "haves" and the "have-nots" can be used to stop such distribution and exclude free-riders from the circle of "sharing."

\section{Sounding out the acceptable levels of "yoashi" and "chiquish"}

According to villagers, "aquinquin (sharing)" has another meaning of "helping each other." This suggests that in order for people to belong to the circle of "sharing," they must offer positive opportunities for "aquinquin" to others so as to "help" them. Just asking others to "help (oneself)" is not approvable behavior. It is not certain whether those who started to blame the "yoashi" household because of their lacking "care for others" were aware of the other bidirectional meaning of "aquinquin," namely "helping each other." This situation shows that the understanding of the notion of "yoash $i$ " and "chiquish" is not unified among villagers, and their meanings have changed due to the influence from the outside world. Concerning "sharing (aquinquin)," dynamic and interactive process of distribution is practiced by villagers including those who are considered to be "yoash" and "chiquish," and in that process, they sound out acceptable (and non-acceptable) behaviours of "yoashi" and "chiquish" in their daily life.

\section{CONCLUSION}

In D Village bananas are the major staple food that is eaten most frequently. However, most households do not supply their own needs, and they acquire and exchange bananas through various processes: they get the fruit through requests, as gifts, in requital/exchange, and through purchase in the village, as well as through requests for harvesting made by the "have-nots" or the gift of harvesting permission by the "haves," both of which are made through face-to-face communication, as well as distribution without tacit permission or formal notification by field owners. While the prior literature pointed out the importance of bananas as a staple food and food exchange as a foundation of Shipibo society, it 
said merely that distribution is based on the kinship, and offered no detailed descriptions. This study revealed the reality that the mutual exchange of bananas is found only in a certain lineage, and found that the Shipibo actively practice various types of food distribution that are not kinship-related.

This article described the distribution of the Shipibo's staple food of bananas in detail, and also demonstrated that the "sharing" in their society is not a stable social custom but a dynamic nexus of interaction among villagers based on the notions of "chiquish" and "yoashi" whose meanings and criteria can change according to statements expressed in their daily communication and interaction and also due to external influence. Then, the Shipibo people have continued banana distribution with a core notion of "aquinquin," but it is not an essentialistic and stable custom, rather in reality, is the dynamic process of rearranging the meanings of "chiquish" and "yoashi" for day-to-day as villagers sound out each other's acceptable situation in their daily life.

It must be noted that while "chiquish" were excluded from the circle of banana distribution, they were not completely exiled from the all village networks; they continued giving fish to other households and invited them for fruit snacking, and also they were able to receive food through other household. The complexity of the bundle of networks in the Shipibo society will be a theme for further research.

ACKNOWLEDGMENTS This research has been supported by Financial Assistance for Researchers Working on for Scholarly Activities Abroad from the University of Tokyo and Grant in Aid for Scientific Research (A), "Conditions for developing collaborative governance of forests in accordance with the locality" (Headed by INOUE Makoto, No. 19208014).

\section{REFERENCES}

Bergman RW. 1980. Amazon Economics: The Simplicity of Shipibo Indian Wealth. University Microfilms International, Michigan.

Behrens CA. 1984. Shipibo Ecology and Economy, Ph.D.dissertation. Anthropology Department, University of California, Los Angeles.

Behrens CA. 1986. The cultural ecology of dietary change accompanying changing activity patterns among the Shipibo. Human Ecology 14: 367-396.
Behrens CA. 1989. The scientific basis for Shipibo soil classification and land use: Changes in soil-plant association with cash cropping. American Anthropologist 91: 83-100.

Behrens CA. 1992. Labor specialization and the formation of markets for food in a Shipibo subsistence economy. Human Ecology 20: 435-460.

DeBoer WR, Lathrap DW. 1979. The making and breaking of Shipibo-Conibo ceramics. In: Kramer C (ed) Ethnoarchaeology: Implications of Ethnography for Archaeology. Colombia University Press, New York. 102-138.

Eakin L, Lauriault E, Boonstra H. 1980. Bosquejo ethnografico de los Shipibo-Conibo del Ucayali. Lima Ignacio Prado Pastor, Lima.

Eakin L, Lauriault E, Boonstra H. 1986. People of the Ucayali: The Shipibo and Conibo of Peru. International Museum of Cultures, Dallas, Texas.

Hern MW. 1976. Knowledge and use of herbal contraceptives in a Peruvian Amazon village. Human Organization 35: 9-19.

Hern MW. 1977. High Fertility in Peruvian Amazon indian village. Human Ecology 5: 355-368.

Hern MW. 1992. Shipibo polygyny and patrilocality. American Ethnologist 119: 501-521.

Hern MW. 2003. Shipibo. In: Ember, Carol R. and Melvin Ember (eds.) Encyclopedia of Sex and Gender: Men and Women in the World's Cultures Topics and Cultures 2. Plenum Pub Corporation, New York. 806-815.

Hiraoka M. 1985. Floodplain farming in the Peruvian Amazon. Geographical Review of Japan 1: 1-23.

Imamura K. 1993. Co-operation and sharing among the central Kalahari San. Journal of African Studies 42: 1-25, in Japanese.

Kakeya M. 1983. Ecological anthropology of envy: A case study in Africa. In: Otsuka R. (ed.) Spirit of Modern: Ecological Anthropology. Shibundo, Tokyo. 229-241, in Japanese.

Kitanishi K. 1997. Food sharing and residential groups of the Aka hunter-gatherers in Northeastern Congo. Journal of African Studies 51: 1-28, in Japanese.

Lathrap DW. 1970. The Upper Amazon. Thames and Hudson, New York.

Matsumura K. 2007. Dynamics of possession and distribution. Japanese Journal of Cultural Anthropology 72: 141-163, in Japanese.

Murdock GP. 1967. Ethnographic Atlas Pittsburgh. University of Pittsburgh Press, Pittsbuigh.

Myers TP. 1990. Sarayacu: Ethnohistorical and 
archeological investigations of a nineteenth-century Franciscan mission in the Peruvian Montana. Lincolon, University Nebraska Studies, New Series No, 68.

O’Neill GA, Dawson I, Sotelo-MC, Guarino L, Guariguata M, Current D, C. Weber J. 2001. Strategies for genetic conservation of tree in the Peruvian Amazon. Biodiversity and Conservation 10: 837-850.

Putsche L. 2000. A reassessment of resource depletion, market dependency, and culture change on a Shipibo reserve in the Peruvian Amazon. Human Ecology 28: 131-462.

Roe PG. 1980. Art and residence among the Shipibo indians of Peru: A study in Micriacculturation. American Anthropologist 82: 42-71.

Sasaoka M. 2008. Wildlife use and the fulfillment of life: socio-cultural meanings of the subsistence use of game animals in a mountain village of Seram island, Eastern Indonesia. Southeast Asian Studies 46: 377419, in Japanese.

Stocks A. 1996. Resource management in an Amazon Verzea lake ecosystem: the Cocamilla case. In: McCAy BJ, Acheson JM. (eds.) The Question of the Commons: The Culture and Ecology of Communal Resources. Arizona Studies in Human Ecology, Arizona. 108-120.

Tournon J. 1988. Las indundaciones y los patrones de occupation de las orillas del ucayari por los ShipiboConibo. Amazonía Peruana 16: 43-66.

Received $5^{\text {th }}$ Feb. 2011

Accepted $24^{\text {th }}$ June 2011 